\title{
$11: 74678732-74654811$
}

National Cancer Institute

\section{Source}

National Cancer Institute. 11:74678732-74654811. NCI Thesaurus. Code C41722.

Physical location of ARRB1_Gene 